\title{
What is Lifelong Learning to First-Year Engineering Students? Creating a Baseline for Future Development
}

\section{Dr. Krista M. Kecskemety, Ohio State University}

Krista Kecskemety is a Senior Lecturer in the Engineering Education Innovation Center at The Ohio State University. Krista received her B.S. in Aerospace Engineering at The Ohio State University in 2006 and received her M.S. from Ohio State in 2007. In 2012, Krista completed her Ph.D. in Aerospace Engineering at Ohio State. Her engineering education research interests include investigating first-year engineering student experiences, faculty experiences, and the connection between the two.

\section{Mr. Jacob T Allenstein, Ohio State University}

Jacob T Allenstein is a graduate student in Aerospace Engineering at The Ohio State University in the process of a Ph.D. Jacob received his B. Sci in Aerospace Engineering in June of 2011 and a Master of Science (Aerospace Engineering) in December 2013. Currently, he is a graduate teaching associate (GTA) for the Engineering Education Innovation Center (EEIC) at The Ohio State University where he multimanages both first year engineering students in the First Year Experience Program and senior capstone students going through the Multidisciplinary Capstone Program. Outside teaching, he is also a graduate research associate (GRA) with a research focus on the aerodynamics of jet engines, jet engine simulators, and jet engine testing facilities.

\section{Mr. Robert B. Rhoads, Ohio State University}

Robert B. Rhoads currently functions as the Multidisciplinary Capstone Program Coordinator for the Engineering Education Innovation Center at Ohio State University. He has a Bachelor of Science in Mechanical Engineering from Ohio State University and Masters in Business Administration from Regis University. Prior to his involvement as the program coordinator, he had over 12 years of experience in industry with roles that varied from process engineering to sales engineering to design engineering. He has also functioned as an engineering technology faculty for three years at Zane State College in Zanesville, Ohio, where he developed and taught courses that included CAD, solid modeling, statics, strength of materials, machine design, and statistical process control. He is currently active in curriculum development and education research focused on design.

\section{Dr. Clifford A Whitfield, Ohio State University}

Clifford Whitfield currently functions as an Assistant Professor of Practice for the Mechanical and Aerospace Engineering Department and Engineering Education Innovation Center at Ohio State University, and senior engineer for Whitfield Aerospace LLC. He received his doctorate in aeronautical and astronautical engineering, and teaches aerospace engineering courses, and teaches and advises capstone design teams for the Multidisciplinary Capstone Program. He is an engineering practitioner in the areas of aerospace systems design and test engineering, with a background that includes unmanned and manned aircraft and aircraft component design and testing, jet engine test cell facility design and testing, and curriculum development and education research focused on design. 


\section{What is Lifelong Learning in First-Year Engineering Students? Creating a Baseline for Future Development}

\section{Introduction}

Albert Einstein once said, "intellectual growth should commence at birth and cease only at death.” ${ }^{1}$ To develop students who can achieve lifelong learning is a goal of higher education. ${ }^{2}$ Because lifelong learning is vital to an engineer's career, the accreditation board for engineering and technology (ABET) included lifelong learning as one of its student outcomes. ABET states that by graduation students should have "a recognition of the need for, and an ability to engage in life-long learning." 3

At The Ohio State University’s Engineering Education Innovation Center (EEIC), students are offered a wide range of engineering courses through the first-year engineering program and a senior-year multidisciplinary capstone program. A requirement for all first-year engineering students at the university is to complete a two-semester sequence which has been designed to give students a broad understanding of the principles and practices of engineering. There are three different course sequences that students can choose from to fulfill their prerequisite for their specific discipline. The three course sequences are standard, scholars, and honors which are accepted by all 14 engineering disciplines offered at The Ohio State University. The 14 engineering disciplines include the following; aeronautical and astronautical, aviation, biomedical, chemical, civil, computer science, electrical and computer, engineering physics, environmental, food, agricultural, and biological, industrial and systems, material science, mechanical, and welding engineering.

The most common course option for first-year engineering students is the standard first-year engineering program (St). This course sequence focuses on the fundamentals of engineering such as; problem solving, design, computer programming, and engineering graphics. This is the most popular option at the university with approximately 73 percent of engineering students enrolling in this two-course sequence.

The first-year engineering honors program $(\mathrm{H})$ at The Ohio State University is an optional course sequence that is offered to university Honors-designated engineering students. The course sequence is an accelerated program to challenge students that includes the fundamentals of engineering with additional programming content and an intense design-build-test project. Another option for first-year engineering students is the first-year engineering scholars program (Sc). This two course sequence focuses on teaching the fundamentals of engineering with the themes of green engineering, innovation, and social responsibility. Students examine in-depth areas such as alternative energy sources, sustainability, and green manufacturing and building.

Table 1 represents the Autumn 2014 enrollment numbers for the first-year engineering programs at the time this study was conducted. These numbers are based off enrollment at the main campus and do not include enrollment numbers from any of the regional campuses for the university. 
Table 1: Current enrollment for the academic year 2014-2015

\begin{tabular}{c|c}
\hline \hline University First-Year Offering & $\begin{array}{c}\text { Student Enrollment } \\
\text { (Academic Year 2014-2015) }\end{array}$ \\
\hline First-Year Engineering Honors (H) & 394 \\
First-Year Engineering Scholars (Sc) & 238 \\
First-Year Engineering Standards (St) & 1382 \\
Total Enrollment & $\mathbf{2 0 1 4}$ \\
\hline \hline
\end{tabular}

Students are offered the option of participating in honors or scholars based on their college application including GPA, ACT scores, and class rank. Students then self-select to participate in the optional programs or pursue the standard first-year engineering course track. The honors and scholars designations are university-wide and the statistics of the Autumn 2014 freshman class are shown in Table 2. ${ }^{4,5}$

Table 2: University Admission Test Score and Class Rank Statistics

\begin{tabular}{ccc}
\hline \hline & $\begin{array}{c}\text { ACT Score range } \\
\text { (middle 50\%) }\end{array}$ & $\begin{array}{c}\text { High school } \\
\text { class rank }\end{array}$ \\
\hline First-Year Engineering Honors (H) & $32-34$ & On average - top 3 percent \\
First-Year Engineering Scholars (Sc) & $28-30$ & On average - top 8 percent \\
University Admission Profile & $27-31$ & $\begin{array}{c}62 \% \text { ranked in top 10 percent } \\
95 \% \text { ranked in top 25 percent }\end{array}$ \\
\hline \hline
\end{tabular}

In the senior year, engineering students are required to complete a capstone project to satisfy their capstone experience. The EEIC offers a Multidisciplinary Capstone program (MDC) as an option for students to replace their discipline specific capstone experience. Students are partnered with industry companies to improve processes, reduce costs, or create new products. MDC also offers non-engineering students the opportunity to participate thru the EEIC's engineering sciences minor program. This promotes discipline diversity in the program while giving students' academic credit. Through the spring of 2014, the MDC program has included over 20 disciplines (both engineering and non-engineering) with approximately 550 students completing the program. Currently, there are 113 students (academic year 2014-2015) that are enrolled in the program.

It is the goal of these two programs (first-year engineering and the Multidisciplinary Capstone) that the EEIC offers, to prepare the students for the next steps in their career whether that is advanced degrees or working in industry. The programs follow ABET Criteria 3 (a-k) to evaluate the students. The ABET Criteria 3 is listed in Table 2. 
Table 3: ABET Criteria $3(\mathrm{a}-\mathrm{k})$

\begin{tabular}{|c|c|}
\hline Outcome & ABET Criteria 3 \\
\hline $\mathbf{a}$ & an ability to apply knowledge of mathematics, science and engineering \\
\hline $\mathbf{b}$ & $\begin{array}{l}\text { an ability to design and conduct experiments, as well as to analyze and } \\
\text { interpret data }\end{array}$ \\
\hline C & $\begin{array}{l}\text { an ability to design a system, component, or process to meet desired needs } \\
\text { within realistic constraints such as economic, environmental, social, political, } \\
\text { ethical, health and safety, manufacturability, and sustainability }\end{array}$ \\
\hline d & an ability to function on multidisciplinary teams \\
\hline e & an ability to identify, formulate, and solve engineering problems \\
\hline f & an understanding of professional and ethical responsibility \\
\hline g & an ability to communicate effectively \\
\hline $\mathbf{h}$ & $\begin{array}{l}\text { the broad education necessary to understand the impact of engineering } \\
\text { solutions in a global, economic, environmental, and societal context }\end{array}$ \\
\hline $\mathbf{i}$ & a recognition of the need for, and an ability to engage in life-long learning \\
\hline $\mathbf{j}$ & a knowledge of contemporary issues \\
\hline $\mathbf{k}$ & $\begin{array}{l}\text { an ability to use the techniques, skills, and modern engineering tools } \\
\text { necessary for engineering practice }\end{array}$ \\
\hline
\end{tabular}

It can be noted that 'recognize the need for and engage in life-long learning' outcome is recognized by ABET as being important for all possible career paths; therefore, this is an objective of both programs.

The programs are continually developing to enrich the students' experience in the courses and to better prepare them for their professional careers. The investigators are always looking at ways to improve the courses for the students. Based on a survey given to engineering employers that collaborate with the Multidisciplinary Capstone program, 89\% of the surveyed engineering employers ranked lifelong learning as being extremely or very important to an early-career engineer ( $\leq 5$ years experience). ${ }^{6}$ Based on the desire to investigate lifelong learning further and the desired ABET student outcome, the research questions for this study are: What characteristics of lifelong learning do first-year engineering students possess and how do firstyear students from different academic populations compare. Additionally, which characteristics demonstrate the most room for growth throughout their undergraduate education? This will form the foundation of a larger study that will also examine senior engineering students' lifelong learning characteristics and engineering industry views on lifelong learning. 


\section{Methods and Background}

\section{Background}

While the desire to produce graduates who understand the importance of lifelong learning is present in many engineering programs, the definition of lifelong learning and how to measure it remains difficult.$^{2}$ One way to measure lifelong learning is to measure the characteristics that lifelong learners would possess.

Mourtos ${ }^{7}$ developed a different strategy for looking at the definition of lifelong learning and its relationship to the ABET student outcome. In his work, he divided the ABET outcome into the two parts of:

- recognizing the need for lifelong learning and

- the ability to engage in lifelong learning.

Mourtos $^{7}$ developed 14 attributes to measure lifelong learning in students in both of these categories. These measures were then used in course design to ensure that lifelong learning was included and assessed in the curriculum. The methods of assessment included student work, student course reflections, and student surveys. Mourtos ${ }^{7}$ recognizes that the 14 attributes of lifelong learning included in his work may not be comprehensive and was only used as a starting point. Table 4 lists these attributes.

Kirby et al. ${ }^{8}$ developed a quantitative survey tool to measure lifelong learning characteristics using the construct defined by Candy et al. ${ }^{9}$ and Knapper and Cropley. ${ }^{10}$ The work of Candy et al. ${ }^{9}$ was developed using interviews with staff, students, and graduates in Australia. From these surveys, five characteristics of lifelong learning were developed. They include:

- setting goals

- applying appropriate knowledge and skills

- engaging in self-direction and self-evaluation

- locating required information

- adapting their learning strategies to different conditions

\section{Survey Description}

Approximately 900 first-year engineering students at The Ohio State University participated in this study. The survey was administered at the end of the first week of the Autumn 2014 semester. Using an online learning management system, the survey tool used was developed by Kirby et al. ${ }^{8}$ and uses 5.0 Likert scale questions to measure the students in five traits of lifelong learning mentioned above. The statements used are shown in Table 4 and are sorted based on the five characteristics of lifelong learning, not the order in which they were given in the survey. The choices ranged from Strongly Disagree to Strongly Agree to see how the students identified with the statements. Statements with a $(\mathrm{R})$ identify statements that were reverse worded; therefore, a statement of strongly disagree would indicate higher lifelong learning characteristics for those questions. 
Table 4: Survey statements and corresponding lifelong learning characteristic categories

\begin{tabular}{|c|c|c|}
\hline $\begin{array}{l}\text { Reference } \\
\text { Number }\end{array}$ & Survey Statement & $\begin{array}{l}\text { Lifelong Learning } \\
\text { Characteristic }\end{array}$ \\
\hline 1 & $\begin{array}{l}\text { I am able to impose meaning upon what others see as } \\
\text { disorder }\end{array}$ & \multirow{3}{*}{$\begin{array}{c}\text { Applying } \\
\text { Appropriate } \\
\text { Knowledge and } \\
\text { Skills }\end{array}$} \\
\hline 2 & I try to relate academic learning to practical issues & \\
\hline 3 & $\begin{array}{l}\text { When I approach new material, I try to relate it to what I } \\
\text { already know }\end{array}$ & \\
\hline 4 & I prefer problems for which there is only one solution (R) & \multirow{3}{*}{$\begin{array}{l}\text { Adapting their } \\
\text { Learning } \\
\text { Strategies to } \\
\text { Different } \\
\text { Conditions }\end{array}$} \\
\hline 5 & $\begin{array}{l}\text { I can deal with the unexpected and solve problems as they } \\
\text { arise }\end{array}$ & \\
\hline 6 & I feel uncomfortable under conditions of uncertainty (R) & \\
\hline 7 & $\begin{array}{l}\text { I feel others are in a better position than I am to evaluate my } \\
\text { success as a student }\end{array}$ & \multirow{2}{*}{$\begin{array}{l}\text { Engaging in Self- } \\
\quad \text { direction } \\
\text { and Self-evaluation }\end{array}$} \\
\hline 8 & $\begin{array}{l}\text { It is my responsibility to make sense of what I learn at } \\
\text { school }\end{array}$ & \\
\hline 9 & I prefer to have others plan my learning (R) & \multirow{5}{*}{ Setting Goals } \\
\hline 10 & $\begin{array}{l}\text { I seldom think about my own learning and how to improve } \\
\text { it (R) }\end{array}$ & \\
\hline 11 & I feel I am a self-directed learner & \\
\hline 12 & I love learning for its own sake & \\
\hline 13 & $\begin{array}{l}\text { When I learn something new I try to focus on the details } \\
\text { rather than on the 'big picture' (R) }\end{array}$ & \\
\hline 14 & I often find it difficult to locate information when I need it & $\begin{array}{l}\text { Locating Required } \\
\text { Information }\end{array}$ \\
\hline
\end{tabular}

\section{Results and Discussion}

As shown in Table 4, the original survey was intended to group the statements into the five characteristics of lifelong learning. In order to determine the reliability of grouping the statements into these categories, a Cronbach's alpha reliability test was conducted on the groupings that had three or more associated statements. The reliability test indicated that the statements could not be combined for this research; therefore, the following results look at individual questions rather than the five higher-level categories.

\section{Overall Results}

The overall results of the combined three populations are shown in Figure 1. The results show that first-year students identify (above 4.00 mean) with five of the lifelong learning statements. They include relating academic learning to practical issues, approaching new material while 
relating is to what is already known, dealing with the unexpected and solving problems as they arise, taking responsibility to make sense of what they learn at school, and loving to learn for its own sake (survey statements $2,3,5,8$, and 12 ). The respondents also indicated a neutral rating ( 3.00 mean) for four statements. These statements include preferring problems that only have one solution, feeling uncomfortable under conditions of uncertainty, feeling others are in a better position to evaluate their success, preferring others to plan their learning, and focusing on details rather than on the big picture (survey statements 4, 6, 7, 9, and 13).

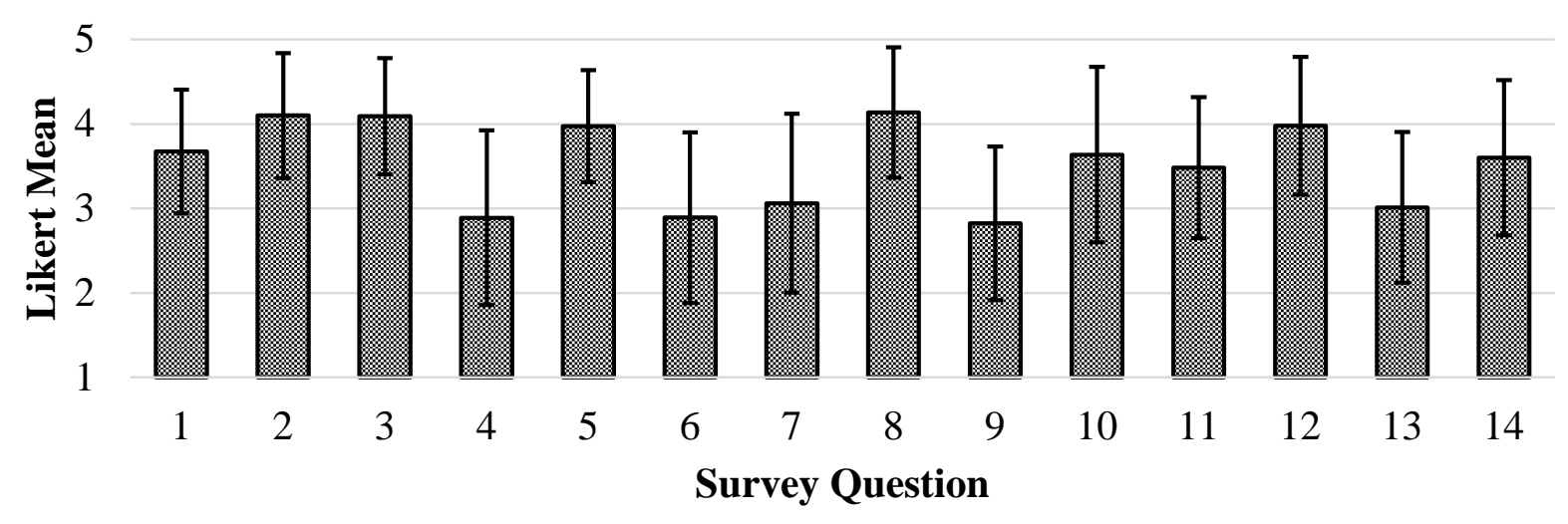

Figure 1: Survey results, Likert mean with bars showing the standard deviation of responses.

\section{Comparing First-Year Student Populations}

Figures 2, 3 and 4 compare the three populations (H, Sc and St) to each other. The individual populations show similar trends as the combined results. A detailed comparison analysis of the three populations follows.

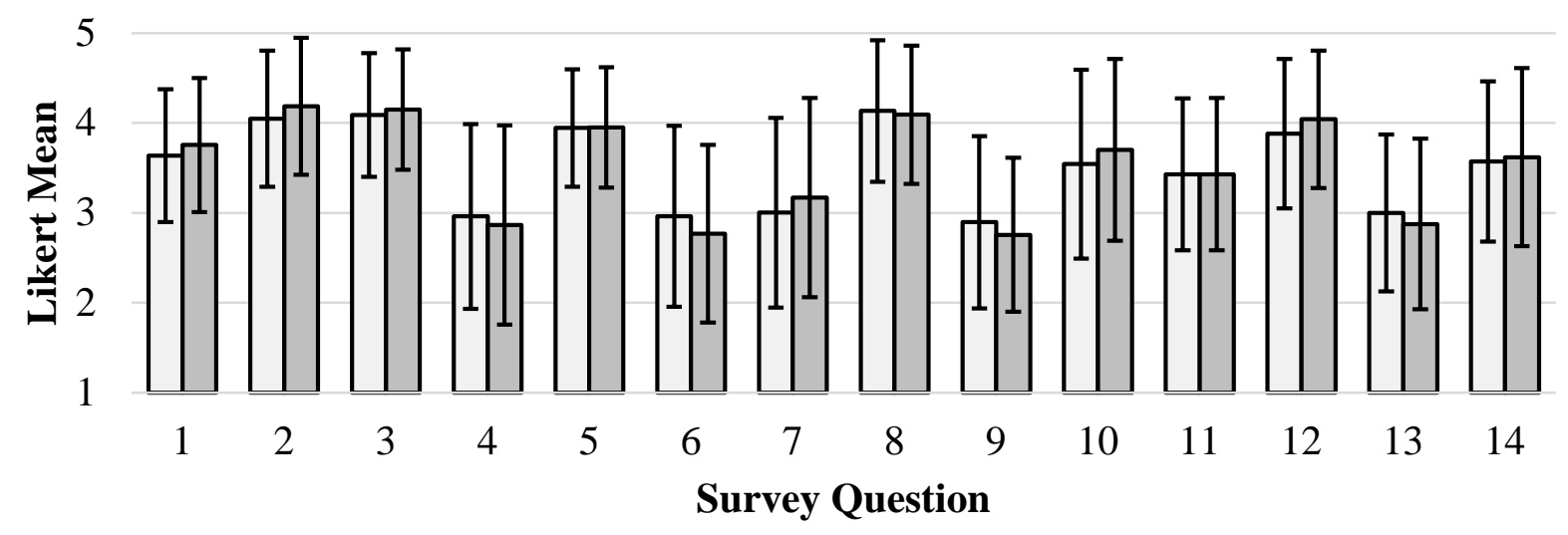

$$
\begin{aligned}
& \square S t(N=497) \quad \text { 口Sc (N=176) } \\
& \text { *Sc = Scholars, St = Standard }
\end{aligned}
$$

Figure 2: Survey results comparing the scholars and standard student population, Likert mean with bars showing the standard deviation of responses 


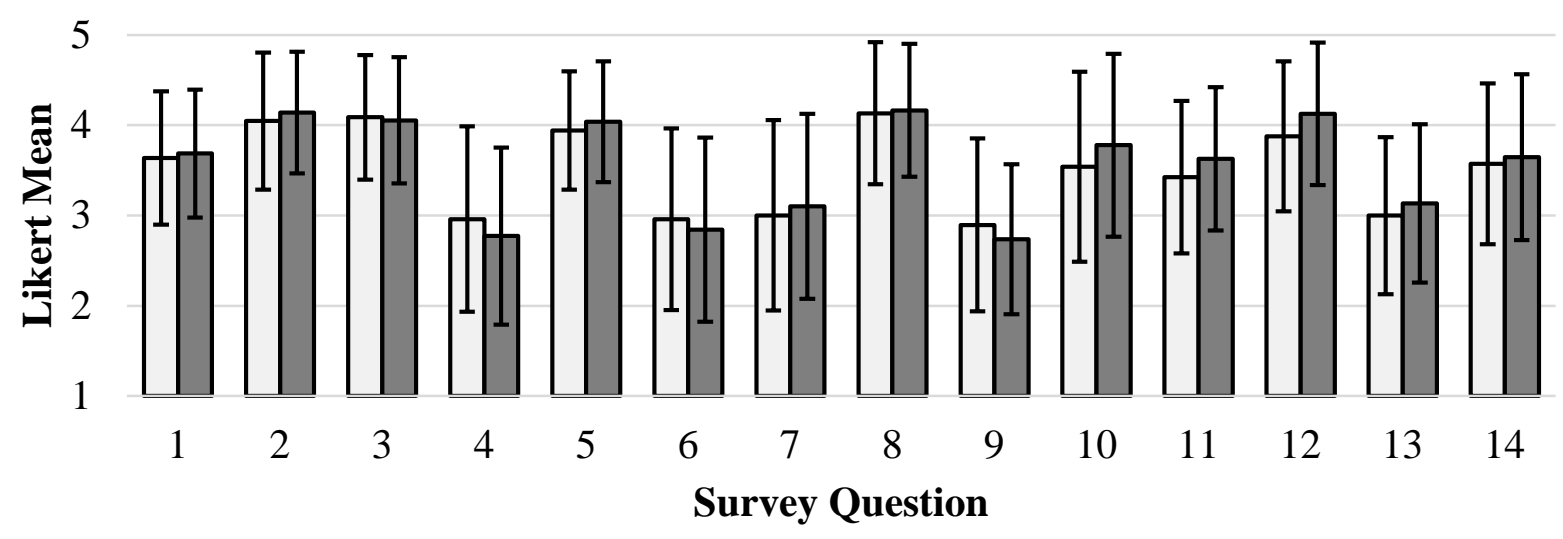

口St (N=497) 口H (N=254)

${ }^{*} \mathrm{H}=$ Honors, $\mathrm{St}=$ Standard

Figure 3: Survey results comparing the honors and standard student population, Likert mean with bars showing the standard deviation of responses

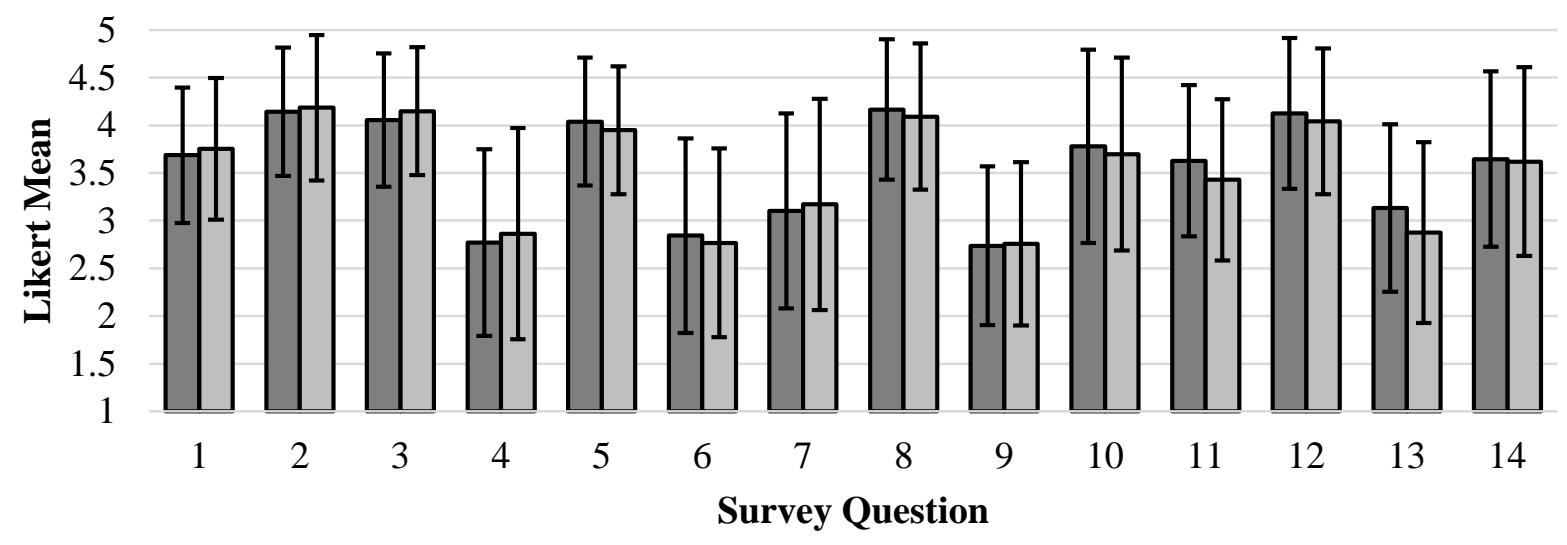

$\square \mathrm{H}(\mathrm{N}=254) \quad \mathrm{QSc}(\mathrm{N}=176)$

${ }^{*} \mathrm{H}=$ Honors, $\mathrm{Sc}=$ Scholars

Figure 4: Survey results comparing the scholars and honors student population, Likert mean with bars showing the standard deviation of responses

Because the results of the survey were non-normally distributed, a Mann-Whitney U test was conducted comparing the different academic student populations to determine if any of the differences between student populations ( $\mathrm{H}, \mathrm{Sc}$, and St) were statistically significant. Table 5 shows the statements that had statistically significant differences ( $\mathrm{p}$-value $<0.05$ ). Statements with a (R) identify statements that were reverse coded prior to being computed 
Table 5: Statistically Significant Survey Results Comparing First-Year Student Populations

\begin{tabular}{|c|c|c|c|}
\hline $\begin{array}{l}\text { Reference } \\
\text { Number }\end{array}$ & Survey Statement & Mean & $\begin{array}{l}\text { Std. } \\
\text { Deviation }\end{array}$ \\
\hline 2 & I try to relate academic learning to practical issues & $\begin{array}{l}\text { St: } 4.047 \\
\text { Sc: } 4.185\end{array}$ & $\begin{array}{l}\text { St: } 0.758 \\
\text { Sc: } 0.763\end{array}$ \\
\hline 4 & $\begin{array}{l}\text { I prefer problems for which there is only one solution } \\
\text { (R) }\end{array}$ & $\begin{array}{l}\text { St: } 2.960 \\
\text { H: } 2.772\end{array}$ & $\begin{array}{l}\text { St: } 1.029 \\
\text { H: } 0.980\end{array}$ \\
\hline 5 & $\begin{array}{l}\text { I can deal with the unexpected and solve problems as } \\
\text { they arise }\end{array}$ & $\begin{array}{ll}\text { St: } & 3.944 \\
\text { H: } & 4.040\end{array}$ & $\begin{array}{l}\text { St: } 0.655 \\
\text { H: } 0.671\end{array}$ \\
\hline 6 & $\begin{array}{l}\text { I feel uncomfortable under conditions of } \\
\text { uncertainty (R) }\end{array}$ & $\begin{array}{l}\text { St: } 2.960 \\
\text { Sc: } 2.767\end{array}$ & $\begin{array}{l}\text { St: } 1.007 \\
\text { Sc: } 0.990\end{array}$ \\
\hline 9 & I prefer to have others plan my learning (R) & $\begin{array}{l}\text { St: } 2.895 \\
\text { H: } 2.736\end{array}$ & $\begin{array}{l}\text { St: } 0.957 \\
\text { H: } 0.832\end{array}$ \\
\hline 10 & $\begin{array}{l}\text { I seldom think about my own learning and how to } \\
\text { improve it (R) }\end{array}$ & $\begin{array}{l}\text { St: } 3.541 \\
\text { H: } 3.780\end{array}$ & $\begin{array}{l}\text { St: } 1.052 \\
\text { H: } 1.013\end{array}$ \\
\hline 11 & I feel I am a self-directed learner & $\begin{array}{l}\text { Sc: } 3.429 \\
\text { H: } 3.629 \\
\text { St: } 3.426 \\
\text { H: } 3.629\end{array}$ & $\begin{array}{l}\text { Sc: } 0.847 \\
\text { H: } 0.795 \\
\text { St: } 0.845 \\
\text { H: } 0.795\end{array}$ \\
\hline 12 & I love learning for its own sake & $\begin{array}{l}\text { St: } 3.879 \\
\text { Sc: } 4.041 \\
\text { St: } 3.879 \\
\text { H: } 4.126\end{array}$ & $\begin{array}{l}\text { St: } 0.831 \\
\text { Sc: } 0.765 \\
\text { St: } 0.831 \\
\text { H: } 0.790\end{array}$ \\
\hline 13 & $\begin{array}{l}\text { When I learn something new I try to focus on the } \\
\text { details rather than on the 'big picture' (R) }\end{array}$ & $\begin{array}{l}\text { St: } 2.998 \\
\text { H: } 3.134 \\
\text { Sc: } 2.875 \\
\text { H: } 3.134\end{array}$ & $\begin{array}{l}\text { St: } 0.872 \\
\text { H: } 0.879 \\
\text { Sc: } 0.948 \\
\text { H: } 0.879 \\
\end{array}$ \\
\hline
\end{tabular}

* St $=$ Standard, $\mathrm{Sc}=$ Scholars, $\mathrm{H}=$ Honors

There were 12 comparisons that resulted in statistically significant differences, 7 between the honors and standard populations, 3 between the scholars and standard population, and 2 between the scholars and honors populations. Three statements resulted in two populations being similar and statistically different from the third population. Figure 5 shows the survey results for the self-directed learner statement (survey statement 11). The honors students agreed with this statement more strongly than the scholars and standard students. 
11. I feel I am a self-directed learner

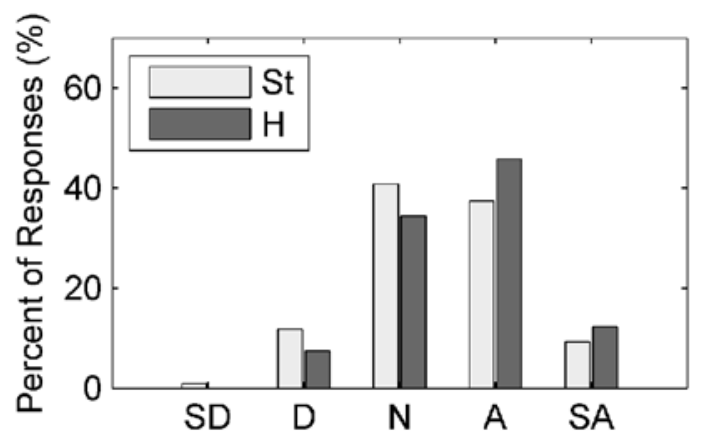

11. I feel I am a self-directed learner

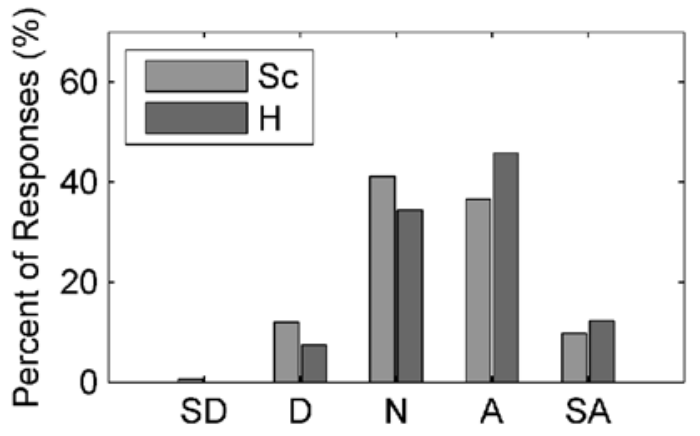

* SD=Strongly Disagree, $\mathrm{D}=$ Disagree, $\mathrm{N}=$ Neutral, $\mathrm{A}=$ Agree, $\mathrm{SA}=$ Strongly Agree

Figure 5: Survey response results of the statistically significant academic populations for survey statement 11 (p-value <0.05).

One area where the honors and scholars students were similar was with the statement about loving learning for its own sake (statement 12), shown in Figure 6. In this case, both the honors and scholars populations reported higher averages compared to the standard students.

12. I love learning for its own sake

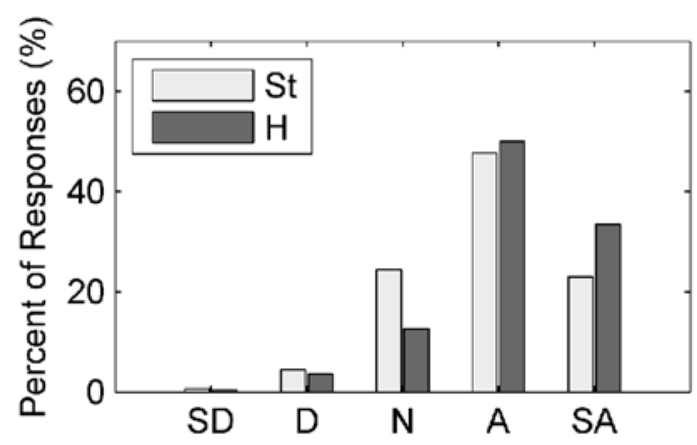

12. I love learning for its own sake

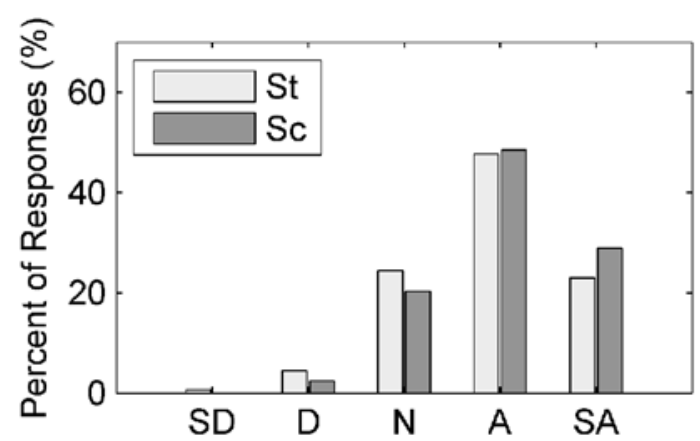

* $\mathrm{SD}=$ Strongly Disagree, $\mathrm{D}=$ Disagree, $\mathrm{N}=$ Neutral, $\mathrm{A}=$ Agree, $\mathrm{SA}=$ Strongly Agree

Figure 6: Survey response results of the statistically significant academic populations for survey statement 12 (p-value <0.05).

The honors population reported focusing on the bigger picture (survey statement 13) more than both the standard and scholars populations, as shown in Figure 7. In this case, the standard and scholars populations did not result in statistically significant differences. 
13. When I learn something new I try to focus'

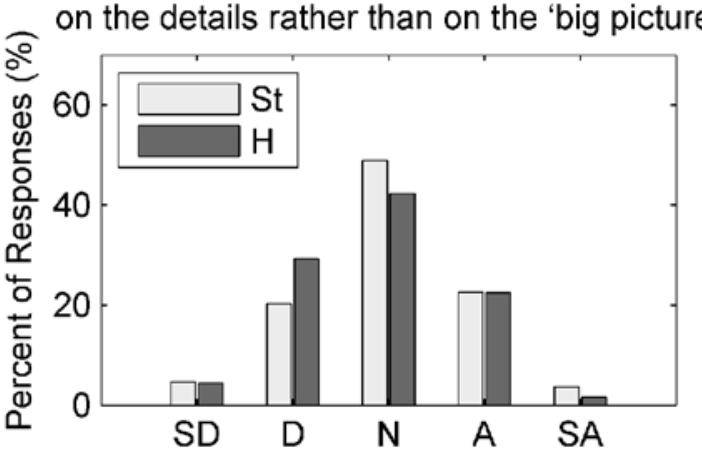

13. When I learn something new I try to focus'

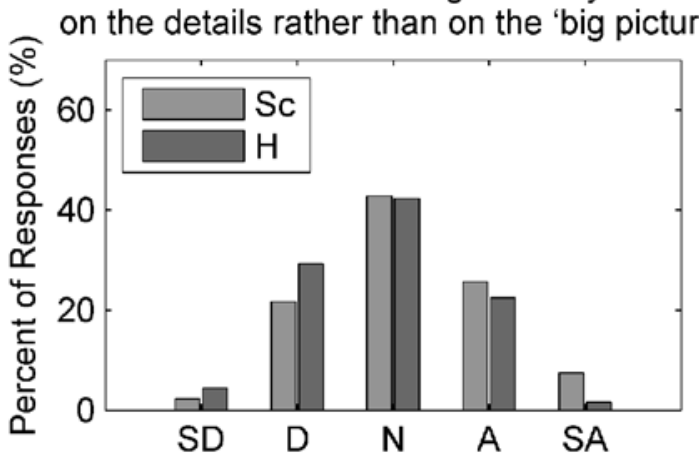

* SD=Strongly Disagree, $\mathrm{D}=$ Disagree, $\mathrm{N}=$ Neutral, $\mathrm{A}=$ Agree, $\mathrm{SA}=$ Strongly Agree

Figure 7: Survey response results of the statistically significant academic populations for survey statement 12 (p-value <0.05).

In addition to the statements above that had more than one population difference, Figure 8 and Figure 9 show the other statements that were different. Figure 8 shows the distribution of the survey results for statements comparing the honors and standard populations. In these cases, none of the responses were reversed for these figures. Regarding statement 4, the honor students indicated a higher preference for problems with only one solution compared to standard students. Statement 5 results show that honor students can deal with the unexpected and solve problems as they arise. Honor students also indicated a higher preference to have others plan their learning compared to standard students (survey statement 9). It is interesting that honors students indicated a higher interest in having others plan their learning, while they indicated a higher amount spend time thinking about their learning and how to improve it compared to the standard students (survey statement 10). The relationship between these statements will be tracked in further studies.

Figure 9 shows the statements with differences that were only between the standard and scholars students. The standard students indicated a much higher percentage that strongly agreed that they try relating their academic learning to practical issues (survey statement 2). The standard students indicated that they are more comfortable under conditions of uncertainty than the scholars students (survey statement 6). 


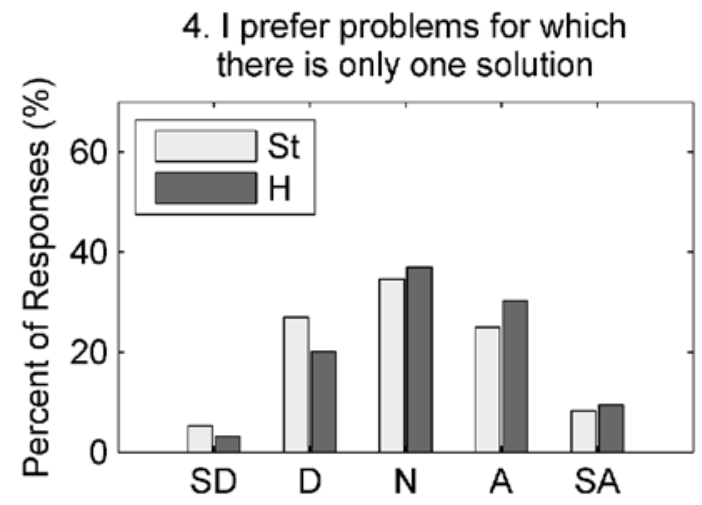

9. I prefer to have others plan my learning

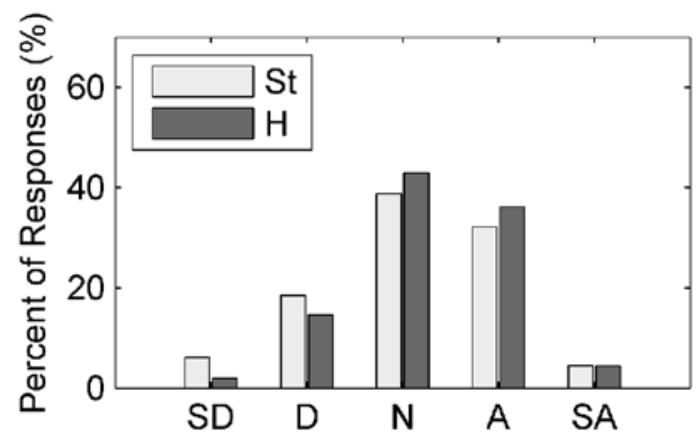

5. I can deal with the unexpected and solve problems as they arise

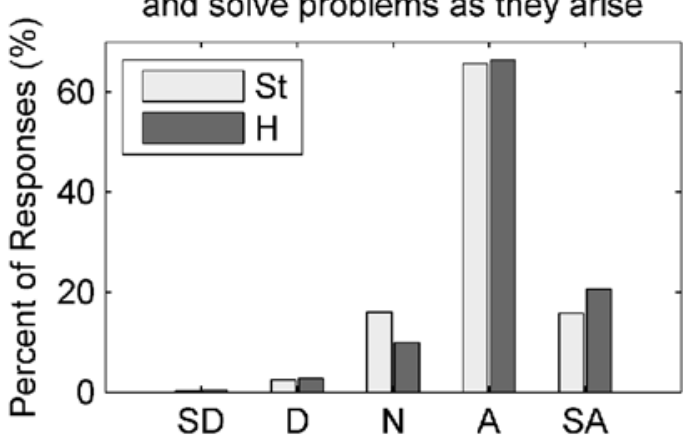

10. I seldom think about my own learning and how to improve it

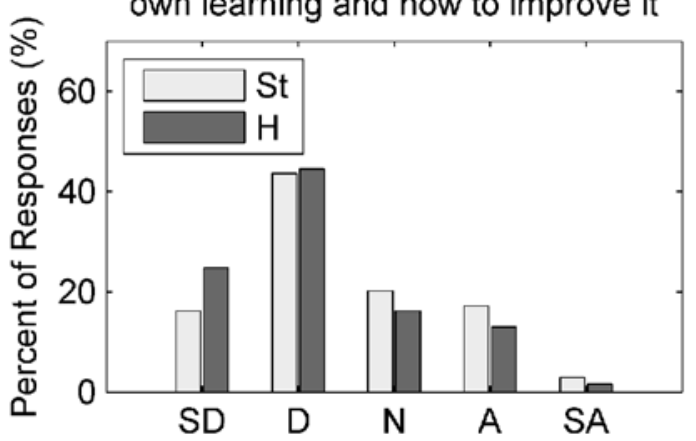

* $\mathrm{SD}=$ Strongly Disagree, $\mathrm{D}=$ Disagree, $\mathrm{N}=$ Neutral, $\mathrm{A}=$ Agree, $\mathrm{SA}=$ Strongly Agree

Figure 8: Honors and standard academic population statements that resulted in statistically significant differences (p-value $<0.05$ ).
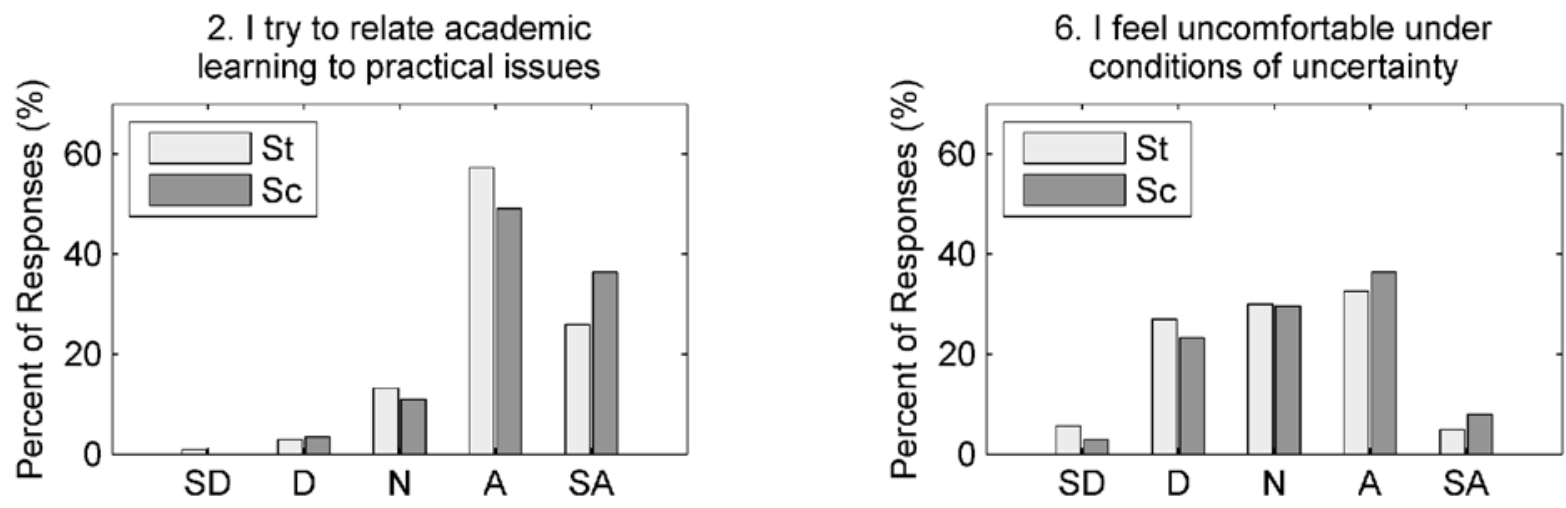

* SD=Strongly Disagree, $\mathrm{D}=$ Disagree, $\mathrm{N}=$ Neutral, $\mathrm{A}=$ Agree, $\mathrm{SA}=$ Strongly Agree

Figure 9: Scholars and standard academic population statements that resulted in statistically significant differences ( $\mathrm{p}$-value $<0.05$ ) 


\section{Conclusions}

Approximately 900 first-year engineering students at The Ohio State University participated in a survey to examine characteristics of lifelong learning. The survey results identified self-reported areas of strengths in lifelong learning characteristics, areas with the most potential for growth, and allowed for a comparison between different student populations.

Overall, The Ohio State University's first-year engineering students identify ( $>4.00$ Likert mean) with five lifelong learning statements. First-year students relate academic learning to practical issues, approach new material while relating it to what is already known, deal with the unexpected and solving problems as they arise, take responsibility to make sense of what they learn at school, and love to learn for its own sake. The research also compared three first-year engineering populations (honors, scholars and standard students) which resulted in nine lifelong learning characteristic statements showing statistically significant differences. Based on these differences, it may be helpful to focus on certain lifelong learning characteristics in some populations instead of others. For example, the honors students identified more with being a self-directed learner than the standard and scholars students. Faculty may consider ways to increase this self-directed behavior in the first-year classroom for the standard and scholars populations. In addition, further research can investigate honors student skill development prior to enrolling in college.

There were three statements that had means for all three populations under 3.00. A rating of 3.00 indicate a neutral response, thus these statements provide the areas with the most room for student growth. These statements include: "I prefer problems for which there is only one solution", "I feel uncomfortable under conditions of uncertainty" and "I prefer to have others plan my learning”. The first two statements indicate first-year engineering students wanting single answers and being more comfortable in situations that are known and clearly defined. This contrasts with the likely roles of an engineer, solving problems that do not have a clear answer, and being able to adapt to situations of uncertainty. These two statements will be interesting to see if there is a change seen in this area in the graduating senior engineering students. The final statement about the planning of learning is not surprising given that students, especially first-year students, look to professors to plan their learning. This is another area that could potentially shift throughout a student's undergraduate career as they begin to take more responsibility for their learning.

The work presented here examines lifelong learning characteristics present in beginning firstyear engineering students. The purpose of this study was to examine how incoming students relate to the lifelong learning statements and determine areas for growth where lifelong learning skill interventions could be developed and used in the curriculum. Because this is only the first step in this study, additional studies will examine the lifelong learning characteristics of senior engineering students to determine what if any differences exist between them and the first-year engineering students. Further studies will also investigate industry views of lifelong learning to help develop the needed interventions.

The authors of this paper are involved in the first-year engineering and Multidisciplinary Capstone programs and are continually developing the programs to enrich the students' 
experience in the courses and to better prepare them for their professional careers. This current study will form the foundation of future studies and improvements to the engineering curriculum.

\section{References}

1. Brazeau, Gayle. A. "Is There Time for Student Intellectual Development and Scholarly Pursuits?” American Journal of Pharmaceutical Education, Vol. 74, No 2, Article 18. 2010.

2. Chen, John C., Lord, Susan M., and McGaughey, Karen J. “Engineering Students’ Development as Lifelong Learners." $120^{\text {th }}$ American Society for Engineering Education Annual Conference \& Exposition. June 24-26, Atlanta, GA, 2013.

3. ABET, 2013-2014 Criteria for Accrediting Engineering Programs. Accessed: October 7, 2014.http://www.abet.org/uploadedFiles/Accreditation/Accreditation_Step_by_Step/Accreditation_Documents/ Current/2013_-2014/eac-criteria-2013-2014.pdf

4. Honors \& Scholars FAQs. Accessed: January 26, 2015. http://honors-scholars.osu.edu/honors/faqs

5. Undergraduate Admissions Quick Facts. Accessed: January 26, 2015. http://undergrad.osu.edu/admissions/quick-facts.html

6. Rhoads, Robert B, Whitfield, Clifford A., Allenstein, Jacob T, and Kecskemety, Krista M. "Industry Sponsor Valuation of a Multidisciplinary Capstone Program” $122^{\text {nd }}$ American Society for Engineering Education Annual Conference \& Exposition. June 14-17, Seattle, WA, 2015.

7. Mouros, N. J. "Defining, teaching and assessing lifelong learning skills." Frontiers in Education, 2003. FIE 2003 33rd Annual. Vol. 1. IEEE, 2003.

8. Kirby, John R., Knapper, Christopher, Lamon, Patrick, and Egnatoff, William J. "Development of a scale to measure lifelong learning.” International Journal of Lifelong Education. Vol. 29, Iss. 3, 2010.

9. Candy, Philip C., Crebert, Gay, and O’Leary, Jane. National Board of Employment, Education, and Training. Australia. No. 28., 1994.

10. Knapper, Christopher K. and Cropley, Arthur J. Lifelong Learning in Higher Education. London: Kogan Page, 2000. 